\title{
Late histological aspects of spleen autologous transplantation in rats ${ }^{1}$
}

\author{
Aspectos histológicos tardios do transplante autólogo de baço em ratos
}

\author{
Rodolfo Malagói, Norair Salviano Reis", Marina Rachel Araújo ${ }^{I I I}$, Nelson Adami Andreollo ${ }^{\text {IV }}$

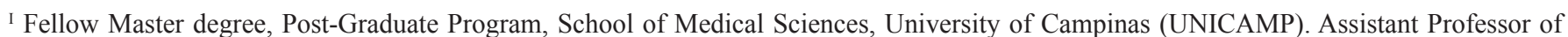 \\ Animal Anatomy, University Center of Itajuba - MG, Brazil.

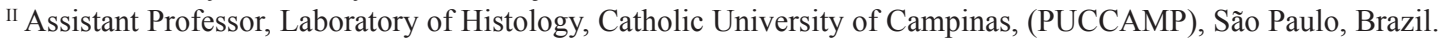 \\ III Biologist, Laboratory of Enzymology and Experimental Carcinogenesis, UNICAMP, São Paulo, Brazil. \\ ${ }^{\text {IV }}$ Full Professor, Digestive Disease Division, Department of Surgery, UNICAMP, São Paulo, Brazil.
}

\begin{abstract}
Purpose: To evaluate macro and microscopically the late evolution of autotransplants of fragments of spleen in the greater omentum, mesenterium and peritoneal cavity, after 24 weeks of observation. Methods: Fifty two Wistar rats were used, males and adults, submitted to total splenectomy and divided in four groups. The group I - seventeen animals with implant of spleen fragment in the peritoneal cavity; group II - eighteen animals with implant in the omentum and group III - seventeen animals with implant fixed in mesenterium root. The group control (group IV) was formed by eight animals chosen aleatorily among the three groups. It was analyzed macro and microscopically the evolution of the implant, and in the histological study qualitative and quantitative criteria were adopted, with the counting of no cellular e cellular elements. Results: It was observed adherences to the adjacent tissues and vascularization in all of the fragments transplanted. The group I presented white pulp and preserved vascularization. In the group II were observed white pulp with follicular formations and lymphoid tissue preserved, and the red pulp in cordon aspect and hemorrhagic. In the group III were observed with depletion of white and red pulp, while others evidenced better preservation of the pulps. The counting of lymphocytes revealed significant difference between the groups I and IV and the group III and IV $(\mathrm{p}<0.05)$. The counting of active macrophages revealed significant difference between the groups II and III ( $p$ $<0.05)$ and similarity between II and IV ( $p>0.05)$. The other elements: active macrophages phagocyting hemosiderine, plasmocytes, fibroblasts, fibrocytes, giant cells, monocytes, interstitial spaces and fibers of collagen, did not show significant difference among the groups. Conclusions: The splenic autotransplantation is feasible, being the better place the greater omentum. This research demonstrated through qualitative and quantitative histological analysis that the splenic tissue autotransplanted in the omentum of Wistar rats preserves its function of defense of the organisms.
\end{abstract}

Key words: Spleen. Transplantation, Autologous. Macrophages. Rats.

\section{RESUMO}

Objetivo: Avaliar macro e microscopicamente a evolução tardia do autotransplante de fragmentos de baço no grande epiplon, mesentério e cavidade peritoneal, após 24 semanas de observação. Métodos: Foram utilizados 52 ratos Wistar, machos e adultos, submetidos a esplenectomia total e divididos em quatro grupos. O grupo I - dezessete animais com implante de fragmento de baço solto na cavidade peritoneal; grupo II - dezoito animais com implante no grande epiplon e grupo III - dezessete animais com implante fixado na raiz do mesentério. O grupo controle (grupo IV) foi formado por oito animais escolhidos aleatoriamente entre os três grupos. Foram analisados macro e microscopicamente a evolução do implante, sendo que no estudo histológico foram adotados critérios qualitativos e quantitativos, com a contagem de elementos celulares e não celulares. Resultados: Foram observadas aderências aos tecidos adjacentes e neovascularização em todos os fragmentos transplantados. O grupo I apresentou polpa branca e vascularização preservada. No grupo II foram observadas polpa branca com formação folicular e bainha linfóide, e a polpa vermelha em aspecto cordonal apesar de hemorrágica. No grupo III foram observados alguns cortes histológicos com depleção de polpa branca e vermelha, enquanto outros evidenciavam melhor preservação das polpas. A contagem de linfócitos revelou diferença significativa entre os grupos I e IV e o grupo III e IV $(\mathrm{p}<0,05)$. A contagem de macrófagos ativos revelou diferença significativa entre os grupos II e III $(p<0,05)$ e similaridade entre II e IV $(p>0,05)$. Os outros elementos: macrófagos ativos fagocitando hemossiderina, plasmócitos, fibroblastos, fibrócitos, células gigantes, monócitos, espaços intersticiais e fibras de colágeno, não apresentaram diferença significativa entre os grupos. Conclusões: O autotransplante esplênico é factível, sendo o grande epiplon o melhor local para a sua fixação. Esta pesquisa demonstrou por meio de análise histológica qualitativa e quantitativa que o tecido esplênico autotransplantado no epiplon preserva sua função de defesa dos organismos.

Descritores: Baço. Transplante Autólogo. Macrófagos. Ratos.

1. Research performed at Laboratory of Enzymology and Experimental Carcinogenesis, School of Medical Sciences, University of Campinas (UNICAMP), São Paulo, Brazil. 


\section{Introduction}

The spleen is a lymphoid organ that plays important part in the organism defense, participating in filtration processes, phagocytosis and immunoglobulin production. Therefore, their main functions are: haematopoietic, immunological in the production of lymphocytes, plasmocytes and macrophages, phagocytosis also denominated of haemocatheresis and it is part of the "pool" outlying of blood storage ${ }^{1,2}$. Recent studies showed that the spleen has a role in the lipid metabolism and may influence atherosclerosis ${ }^{3}$. Histologically, the spleen is formed by a stroma and the parenquima being its cellular arrangement differentiated in white and red pulps. The white pulp acts, about $80 \%$ of the parenquima while the remaining $20 \%$ are the red pulp, which is constituted by the lymphoid splenic strings. The main cellular types in the splenic structure are: T and B lymphocytes, macrophages, plasmocytes, fibrocytes, reticulocytes and dendritic cells ${ }^{1,2}$.

The patients victims of spleen traumatisms and splenectomized assume an asplenia state and consequently they acquire a larger susceptibility to the sepses, which can be quickly progressive and fatal, above all with larger incidence in children and hemopaties bearers. Consequently, it has appeared therapeutic options after the splenectomies, using techniques of conservative surgery (conservative treatment, partial splenectomies and splenorrhaphies with or without application of haemostatics agents), as well as techniques of splenic autotransplantation $^{1,2}$.

Therefore, in the attempt to maintain those functions in splenectomized individuals, the autologous implants have good success in experimental studies. The literature is rich in the experimental and clinical works, showing the effectiveness of the autologous graft spleen in the protection of the organism against infections.

Historically, there is more than fifty years, Manley and Marius observed that the small spleen autotransplants had capacity to regenerate ${ }^{4}$. The implant viability is influenced by several factors, such as it size, it forms and place. Several techniques were adopted for the verification of the implants, which could be implanted the whole organ, or a portion as varies from 25 to $50 \%$, or a homogenized tissue form ${ }^{5,7,8}$.

Some authors recommend the autotransplantation in a homogenized tissue form, with the justification that is better to maintain the splenic filter function, because the architecture of the spleen is conserved. Besides, it is discussed if the viability is superior in the implants of smaller fragments for regenerating in less time than the larger implants ${ }^{9,10}$. As for the location of the implants, several places have been studied: great omentum, peritoneal cavity, splenic store, retroperitoneum, intraportal, abdominal muscle, armpits and subcutaneous of abdominal wall $^{7,10}$. The greater omentum has several advantages, as the accentuated vascularization, allowing great sanguine contribution, that it is resulted essential for its appropriate revascularization, which avoids the migration of the implant, and its permanence in the portal territory. The capacity of implant growth in the abdominal muscles is smaller than in the omentum and peritoneum ${ }^{1,11}$.

Sampaio $^{12}$ recorded the first case in the brazilian lit- erature, when during an appendectomy, in a 10 years ago splenectomized patient, he found red-dark nodules of soft consistence dispersing for the mesenterium, cecum, terminal ileum and peritoneum, whose histology revealed splenic tissue. Like this, there are several publications about spleen autotransplantation in humans $5,7,13,14,15$. Recently, Petroianu and Petronianu ${ }^{16}$ related the technique of spleen autotransplantation for the treatment of hypertension portal. Their studies recorded 31 cases of hypertension portal due to schistosomiasis that were submitted to the splenectomy and subsequent implantation of 20 fragments in the omentum. The patients had hematological, immunological and scintillographic evaluations.

Von Stubenrauch ${ }^{17}$ was the first to demonstrate the possibility in dogs whose reduced spleen to fragments was dispersed on the peritoneum, demonstrating for autopsy, three months later, the vitality and perfect adaptation of the graft. Willians et al..$^{15}$ studied autologous grafts spleen done inside of cameras installed in ears of rabbits, which usually showed survival and rebuilding of the Malphigi lobes and capsule, however separately they failed in provoking grafts. And the following years are several the publications about experimental autotransplantations $\mathrm{s}^{5,9,11,17,18,19,20,21}$.

Recently, Marques et al. ${ }^{22}$ submitted young and adults Wistar rats to combined splenectomy followed by autotransplantation at the omentum. Sixteen weeks after the implants, the slices of the splenic tissue were collected for histological analysis and phagocitosis evaluation, observing splenic tissue regeneration in all the animals.

Miko et al. ${ }^{23}$ used morphologic studies, among other techniques, to evaluate rats submitted to the spleen autotransplantation, six weeks after splenectomy. The omentum was preferred as placed and then was done revascularization studies.

Marques et $a l .{ }^{24}$ analyzed the morphologic regeneration of the splenic tissue implanted in 32 Wistar rats, 13 males and 19 females. The spleen slices, split up obliquely of $2 \mathrm{~mm}$ of thickness, were autotransplanted in the omentum and removed after 16 weeks. It was also verified the phagocitosis function of their macrophages through the inoculation of Escherichia coli. All of the rats had splenic tissue regenerated and the young animals presented larger percentile of regeneration.

Souza et al. ${ }^{8}$ observed autologous grafts in 44 Wistar rats, and the first group with 22 animals received the implant in the abdominal subcutaneous tissue, between the area of the flank and the left side, and the second group with 22 animals, in the root of the transverse colon. Both groups were subdivided in two other and they received only fragment or four spleen fragments, being surrounded by themselves these last ones with having distanced $1 \mathrm{~cm}$. The fragments were in slices of $1 \mathrm{~cm}$ and they possessed weight varying between 180 and $200 \mathrm{mg}$. After of five weeks, the animals suffered euthanasia and the fragments removed to histological studies. The criteria of histological evaluation were: 1 - analysis of the constitution of the histological elements and compared with the normal (control) spleen; 2 - analysis of the reaction between the receiving area and the implanted fragments and regenerate. Concomitant the cytological studies were accomplished by the smear of the regenerate and red-faced graft by the Leishmann method.

Paulo et al. ${ }^{25}$ evaluated the technical, morphological 
and functional aspects of the inferior pole of the spleen of a group of 10 Wistar rats submitted to subtotal splenectomy. Other two groups had 10 animals submitted to laparotomy with spleen manipulation (sham operation) and 16 animals submitted to total splenectomy. The rats were sacrificed after 90 days and the implanted tissue and the remainder spleen were macro and microscopic studied with hematoxilin-eosin stain.

Karagülle et $a l .{ }^{26}$ proposed a study of the autotransplant effects in the immunological status, and they examined the viability of splenic implants in 20 rabbits. A group was submitted to only laparotomy, the second group to splenectomy and the third to splenectomy and transplantation in the omentum. The evolution of the grafts was by scintillographic, histopathological and hematological-immunological tests.

Were not found in the consulted literature the histopathological studies focusing late analyses of cellular and no cellular elements of the autotransplantation in different places in the peritoneal cavity.

The objectives of the present research were to evaluate macro and microscopically the late evolution of the autotransplantation of fragments of the spleen in the greater omentum, in the mesenterium and in the peritoneal cavity.

\section{Methods}

Fifty two Wistar rats (Rattus Novergicus Albinus, Rodentia, Mammalia), males, with about 3 months of age and medium weight of $418 \mathrm{~g}$ under room temperature and conditions of natural light, fed with ration for rodents were employed. The animals divided in three groups were submitted to total splenectomy and intra-abdominal spleen tissue autotransplantation, being the Group I with seventeen animals and implant in the cavity; Group II with eighteen animals and implant in the omentum and Group III with seventeen animals and implant in the mesenterium root. The group control (Group IV) was formed by eight animals chosen aleatorily among the three groups. Protocol $\mathrm{n}^{\circ} 745-2$.

\section{Autotransplantation technique}

The anesthetized animals were submitted to laparotomy and to splenectomy. The spleen was put in solution of sodium chloride $0,9 \%$ for cleaning of the excess of blood and dry with aid of a gauze, being weighed then in a precision scale and measured with ruler in milimeters.

The organ was fragmented in three similar portions, and the fragments of the extremities left and right of the spleen were called, respectively, of "F1" and "F3", while the fragment of the middle, called of "F2." The fragments F1 and F3 were put in formalin $10 \%$ for histological studies as controls. The fragment F2 was autotransplanted in the abdominal cavity: in the group I it was left aleatorily in the peritoneal cavity, in the group II it was involved in the greater omentum, very close to the stomach great curvature, being formed a bag which was sutured with thread of 4-0 cotton and in the group III the closest of the mesenterium root was set with aid of thread 4-0 cotton. The procedures total duration time was approximately from 20 to 25 minutes in all the animals.
Sacrifice of the animals, removal of the fragments and histological studies

The animals were observed and after 24 weeks they were anesthetized again and submitted to laparotomy and to inspection of the peritoneal cavity to look for the splenic tissue implanted. The fragments were examined carefully in search of revascularizations and being dissected the adjacent tissues. They were removed and again weighed in a precision scale, and measured with ruler in millimeters.

The collected fragments were conserved in formalin $10 \%$ for histological studies in red-faced cuts using hematoxilineosin stain. Two criteria of histological evaluation were adopted: the qualitative and quantitative analysis.

The qualitative analysis consisted of the evaluation of the fragments, with emphasis in the comparison with the normal splenic tissue being verified the capsule, the white pulp, the red pulp, the splenic tissue structure, and the vascularization.

The quantitative analysis consisted of the counting of cells using a reticulum with 100 quadrants of $1 \mathrm{~mm}^{2}$ each, enclosed to digital pictures of three fields different from each histological sheet, in increase of $100 \mathrm{x}$, through software program Photoshop $^{\circledR}$ (Figure 1).

The quantitative analysis employed two main parameters: the cellular elements and no cellular elements. The cellular elements are: lymphocytes, active macrophages, macrophages with hemosiderine, plasmocytes, endothelial cells, fibrocytes, fibroblasts and giant cells. The no cellular elements are: fibers collagen fibers and interstitial space.

During the quantitative analysis these specific criteria were adopted: to consider the presence of cellular elements, the counting of just a cell for quadrant, the counting of the cell whose nucleus was in the center of the quadrant or closer of him, and also considering the no cellular elements. The cell nucleus that played the left line and the inferior line of the quadrant was conjugated to the respective quadrant. They were counted 300 elements for rat of each group (Figure 1).

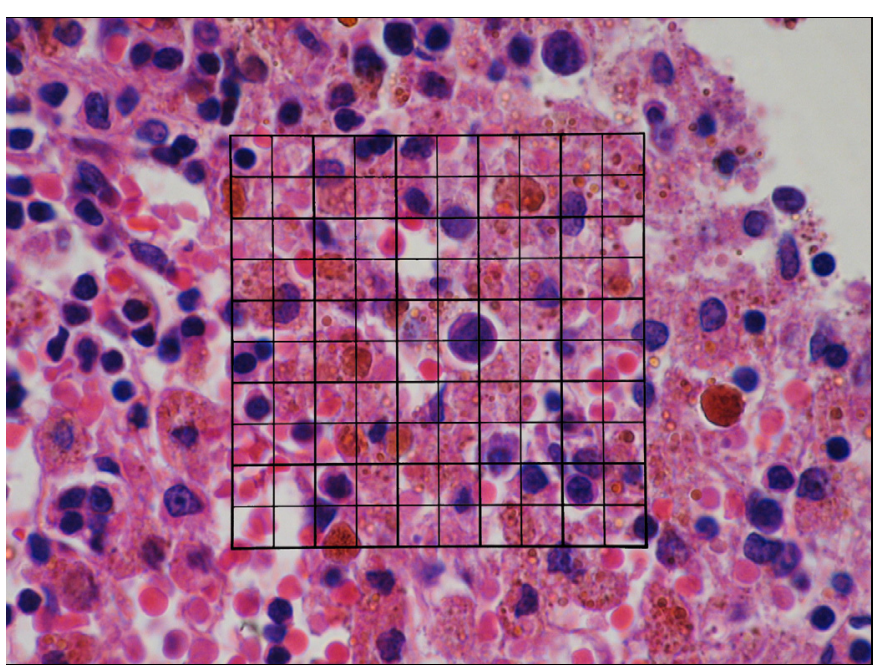

FIGURE 1 - Digital picture of histological cut (H.E. - 100x), put upon with a reticulum with 100 quadrants of $1 \mathrm{~mm}^{2}$ each, used for counting of the cells of the splenic tissue 


\section{Statistical analysis}

Were used descriptive statistical (average, deviationpattern, minimum, medium and maximum) for the continuous variables (weigh and size) and frequency table for the categorical variable (Group). In the homogeneity verification among the groups with relationship the variables weight and size of the spleen was used the Analysis of Variance (ANOVA), with transformation Rank. In the comparison of the variables weight of the rats, weight and size of the fragment of the spleen among the groups (cavity, omentum and mesenterium) and among the moments (before and after implants), were used the Analysis of Variance (ANOVA) for repeated measures, with transformation Rank, due to no existence of normality of the data, to reduce the asymmetry and variability. When the difference was significant, multiple comparison tests were accomplished to identify the differences (Test of Turkey and Contrast). The significance level was of $5 \%(\mathrm{p}<0.05)$.

\section{Results}

All the animals had gain of weight in a homogeneous way after 24 weeks of observation. There were no deaths. However, important reduction was registered in the weight of the splenic tissue implanted in the three groups, being of $31 \%, 34.6 \%$ and $50.3 \%$, respectively in the groups I, II and III (groups I and II versus group II $\mathrm{p}<0.05$ ).

The size of the implanted fragments also suffered reduction. The average size in the preoperative, in the groups I, II and III, respectively, was of $15.19 \mathrm{~mm}, 14.53 \mathrm{~mm}$ and $15.41 \mathrm{~mm}$. After the implant, the average size was, respectively, $13.63 \mathrm{~mm}$, $11.65 \mathrm{~mm}$ and $11.94 \mathrm{~mm}$. Therefore, the percentile rate decreased, respectively, being of $10.2 \%, 19.8 \%$ and $22.5 \%$ (group I versus groups II and III $\mathrm{p}<0.05)$.

\section{Macroscopic analysis of the grafts}

The macroscopic analysis showed, after 24 weeks, that the implants of splenic tissues were visualized easily in the different places, with implantation of the fragments close to the adjacent omentum. The revascularization was observed in all of the fragments of the groups, coming of the omentum or of the mesenterium (Figures 2, 3, 4 and 5).

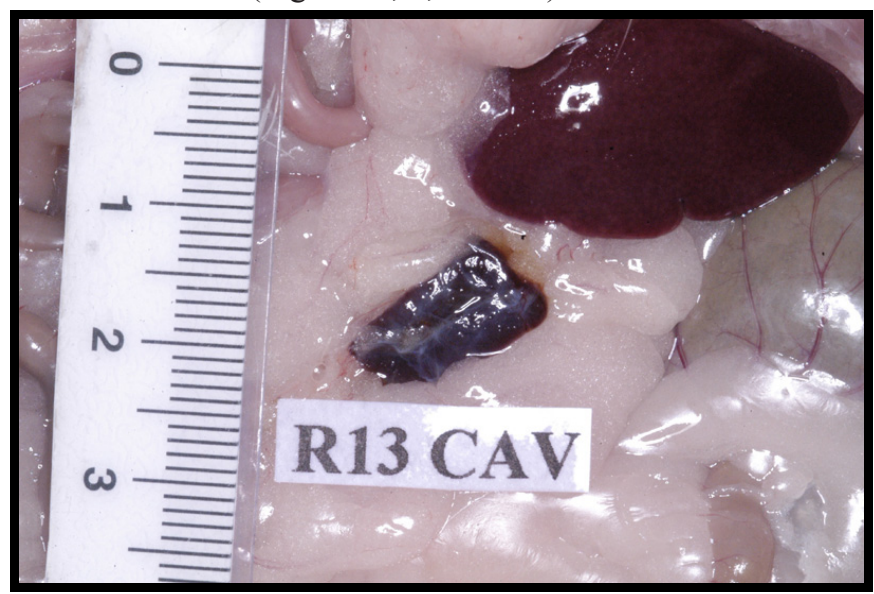

FIGURE 2 - The group I graft, emphasizing its implantation in the adjacent tissues

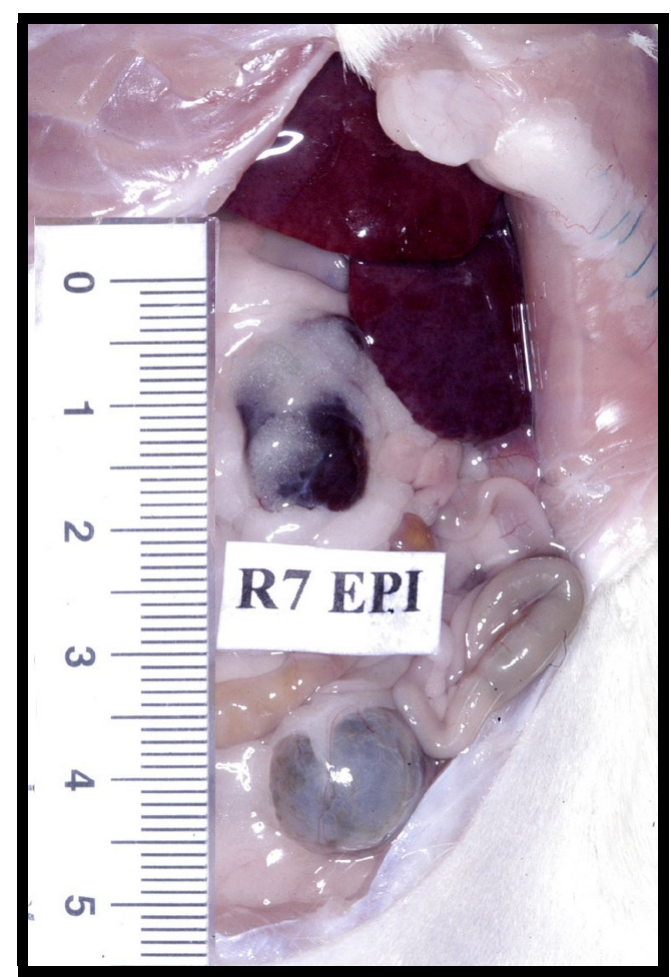

FIGURE 3 - The group II graft, emphasizing its implantation in omentum

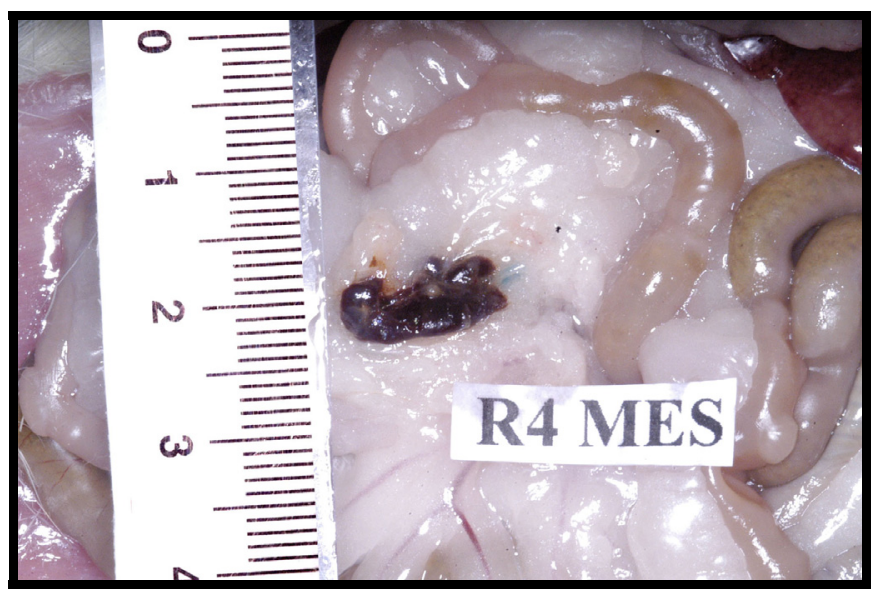

FIGURE 4 - The group III graft, emphasizing its implantation in the mesenterium

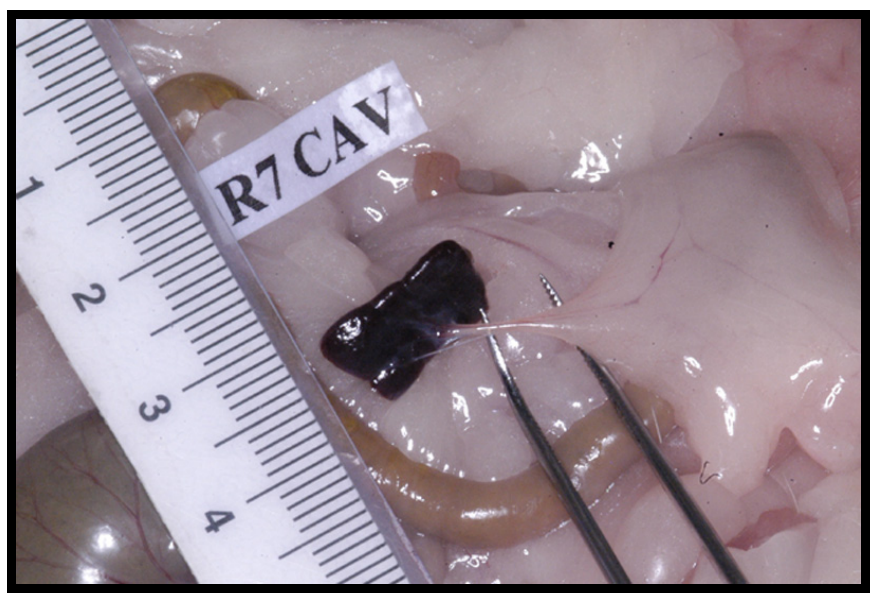

FIGURE 5 - The group I graft with presence of a vessel originating from revascularization of the omentum 


\section{Histological qualitative analysis}

1. Group I (cavity): splenic capsule sometimes normal, other times with hyalinization aspect. The white pulp was preserved. Red cells were verified inside the sinusoid and in the interstitial spaces, besides smaller amount of blast and mult nucleus cells. As for the vascularization, the septal vessels, the arterioles and the sinusoids were well preserved.

2. Group II (omentum): splenic capsule, fine septs and with atrophy aspect, more thickened with hyalinization aspect. The splenic tissue was partially preserved, with the white pulp so much with follicular formations, as in lymphoid tissue and the red pulp with cordon aspect and hemorrhagic. Were found many activated macrophages, with repleted cytoplasm of hemosiderine granules and giant cells.

3. Group III (mesenterium): presence of different evolutionary aspects of the animals amongst themselves, so much rarefaction of splenic tissue and great depletion of the white and red pulps, allied to a considerable red cell destruction, translated by the presence of great macrophages with the replete cytoplasm of hemoglobin or hemosiderine. Significant amount of red cells were found inside vessels and in the interstitial space, besides many mult nucleus cells. The pericapsular tissue presented normal vessels, unilocular fat, sometimes with fibrosis, meaning presence of adherences.

\section{Analysis of the number of lymphocytes}

The lymphocytes average, in the counting of the histological cuts, in the groups I, II, III and IV (control), respectively, was of $17.1,24.3,16.8$ and 32.8

The variance analysis showed significant difference among the groups I and IV and III and IV $(p=0.0020-p<$ $0.05)$, and similarity among the groups II and IV $(\mathrm{p}>0.05)$. Therefore, as for the counting of lymphocytes, the autotransplantation in the omentum was very similar to the control group $(\mathrm{p}>0.05)$.

\section{Analysis of the number of active macrophages}

The active macrophages average, in the counting of histological cuts, in the groups I, II, III and IV, respectively, was of 3.1, 6.1, 7.0 and 5.7.

The variance analysis showed that the group I presented significant difference in relation to the groups II and III ( $\mathrm{p}=$ $0.0370-\mathrm{p}<0.05$ ), and similarity among the groups II and IV ( $\mathrm{p}$ $>0.05)$. Therefore, as for the number of active macrophages, the autotransplantantion in the omentum and in the mesenterium they were very similar to the control group. ing hemosiderine

Analysis of the number of macrophages phagocytiz-

The macrophages phagocytizing hemosiderine average, in the counting of histological cuts, in the groups I, II, III and IV, respectively, was of 9.6, 15.3, 11.9 and 10.7.
The variance analysis revealed that there was not significant difference among the groups. $(p=0.0560-p>0.05)$. Therefore, the three autotransplantation places presented similar numbers of these cells.

\section{Analysis of the number of plasmocytes}

The plasmocytes average, in the counting of the histological cuts, in the groups I, II, III and IV, respectively, was of $0.1,0.6,0.5$ and 03 .

The variance analysis showed no significant difference among the groups $(p=0.3426-p>0.05)$. Therefore, as for the counting of the plasmocytes number, there was significant difference among the autrotransplantation places.

\section{Analysis of the number of endothelial cells}

The endothelial cells average, in the counting of the histological cuts, in the groups I, II, III and IV, respectively, was of $0.7,0.4,1.0$ and 1.8 .

The variance analysis revealed significant difference among the groups II and IV ( $p=0.0409), p<0.05)$. Therefore, the omentum group differed significantly of the control group, and the cavity group and the mesenterium group were similar to the control group in the number of endothelial cells.

The variance analysis comparing the counting of the fibrocytes, giant cells, monocytes, the number of interstitial spaces and collagen fibers showed no significant difference in the groups $(p>0.05)$. Therefore, the three autotransplantation places presented similar numbers of these elements.

\section{Discussion}

Wistar rats are pointed laboratory animals as appropriate for the investigation of the splenic vascularization and they present the spleen relatively larger than other species of mammals ${ }^{1}$. Torres et al. ${ }^{21}$ related that it is an animal of easy manipulation, favoring the subtotal or total splenectomy, due to its anatomical location and still the postoperative to have low operational cost. Despite the morphology peculiar of each species, their histological aspects of the splenic tissue are similar to the humans ${ }^{1}$. Kovacs et al. ${ }^{5}$, studying autologous grafts of rats, concluded that the youngs are more capable to regenerate the splenic tissue and they emphasize that the development of the graft depends not only of the age of the recipient, but also of the local sanguine supply. The regeneration period is very variable, could arrive up to 24 weeks. Experimental studies demonstrated that the more youth is the animal, faster the implanted fragment acquired the structures of normal splenic tissue. Based in those observations in several animal species, therefore it can be suggested that in the children and in the adolescents, implant regeneration can also occur in a faster way than in the adults. If that hypothesis is true, it is presupposed that their beneficial effects would take place exactly in the age group that the spleen is made necessary ${ }^{1,2,27}$.

The authors discuss in their publications the aspects and subjects related to the weight of the transplanted fragment. Like this, Tavassoli et al. ${ }^{9}$ recorded the correlation among the 
initial and final weight of the fragment for smaller implants than $100 \mathrm{mg}$, since for the superior weights the process of degeneration overcomes the regeneration. Besides, they also verified that the final weight of the grafts is a lineal function of the initial weight, since the values do not cross $100 \mathrm{mg}$, when then this relationship stops existing.

Rodrigues et al..$^{28}$ observed the animals for 40 weeks after partial splenectomy and autotransplantation. In the group of implants in the omentum, were found from 4 to 8 fragments, wine color and diameter from 3 to $8 \mathrm{~mm}$. The group submitted to partial splenectomy, the remainder ortothopic spleen presented normal coloration and vascularization. They concluded that of the histopathologic point of view, there was not difference among the grafts in splectomized animals and animals with 50\% of remainder spleen.

Rezende et al..$^{20}$ observed after 16 weeks of autotransplantation, that the omentum in the sliced group presented the largest weight average of splenic tissue, although without statistical difference comparing to the initial weight. The difference of average of the weights varied from 30.88 to $56.75 \mathrm{mg}$.

Paredes et al. ${ }^{11}$ in its experimental study with 25 animals identified that the average of weight of the viable splenic tissue recovered was of $150 \mathrm{mg}$, in intervals that oscillated from 3 to 5 months after the autotransplantation, and the initial weight of the fragments, before the implants, was of $525 \mathrm{mg}$.

Marques et al. ${ }^{22}$ verified that in the young animals, the average of splenic tissue implanted and regenerated, as much as for its regeneration rate, they were higher for the males, however in the adult animals there is no significant difference between the males and the females, after 16 weeks of observation. The weight average of the splenic tissue implanted in the young animals was of $0.51 \mathrm{~g}$ and the recovered tissue was of $0.14 \mathrm{~g}$. The group of the adult animals presented the tissue implanted of $0.67 \mathrm{~g}$ weight average, while in the recovered graft the average was of $0.22 \mathrm{~g}$.

Marques et al..$^{24}$ verified that 16 weeks after the autotransplantation, in the group of young rats, with weight varying between 100 and $150 \mathrm{~g}$ (five males and 14 females), the relative averages to the splenic tissue implanted and the regenerate tissue, as well as the percentile of regeneration, were larger for the males ( $\mathrm{p}=0.0132-\mathrm{p}=0.0010-\mathrm{p}=0.595$, respectively). But, there was no difference among the averages regarding the implants in males and females, in the adult animals. However, the females showed mass regenerate and larger tissue percentile of regeneration $(p=0.0254-p=0.0152$, respectively). Despite there not being reports in the literature that correlation of the hormonal tax with the regeneration of the grafts, the fact of young females presented smaller percentile of regeneration, when compared with the largest rate found in adult females, it can be explained due to not so good hormonal regulation in young animals. Being like this, the largest hormonal liberation after the sexual maturity of the females, it could aid in the regeneration of the implants. Besides, they also verified that the adult rats when compared with the youths, presented the largest relative averages of grafts compared to the regenerate splenic tissue.

About the best place of implantation of the splenic tissue, there are many studies in the consulted literature. Lau and
Ong ${ }^{17}$ studied the macroscopic aspects and the weight of the grafts, and they verified that only in the omentum occurred considerable growth. As for the histological aspects, only in the omentum, the regeneration was integral, similar to spleen miniatures. The splenic follicles, sinusoids and red pulp were present and normal. Other places studied (subcutaneous and retroperitonium), the regeneration was poor and of difficult identification of the splenic architecture. The authors emphasized that the omentum is an appropriate place for the graft development for the largest sanguine supply.

Sotelo et al. ${ }^{19}$ working with autotransplantation of splenic tissue in the ometum, observed histologically that after 30 days, the presence of germinative center, constituted of matured lymphocytes that form true lymphatic nodules and, inside its central section, the presence of an artery of small diameter, denominated follicular artery. Surrounding these areas observed abundant sinusoids, which congestion is shown by the red cells, and among the strings formed by the sinusoids verified the presence of reticulocytes and plasmocytes.

Rezende et al. ${ }^{20}$ verified that in the macroscopic analysis the fragments formed several points of weak adherences, represented by the presence of small adjacent vessels. Besides, they observed by histological sample, high similarity of the splenic tissues in the intra-abdominal places (omentum and root of the mesenterium) with the control group, and in the sliced group it was significantly larger.

Paredes et al. ${ }^{11}$ using histological studies observed hemosiderine deposits in the macrophages in form of cytoplasmic thick granules, giant multi nucleous cells in 15 cases $(57.69 \%)$, solid lipogranulomas with necrosis focuses surrounded by histiocytes and giant multi nucleous cells in two cases $(7.69 \%)$. The fibrosis was found in 13 rats $(50 \%)$ and calcification in two cases $(7.69 \%)$. They also demonstrated that the splenic tissue suffers ischemic necrosis in its central portion extending in a centrifugal way, staying viable just a layer outlying perfused from the neighboring tissue in which a specific inflammation is produced. Starting from to 10th week its become visible the granulomas and later the sclerosis, that advanced centripetally in the necrosis. At peripheric level, the differentiation of the splenic tissue begins, appearing irregular sinusoids brought by reticulocytes and endothelial cells, accumulations of lymphocytes and monocytes and reticular fibers that constituted the connective splenic tissue, and the vascularization coming from the conjunctive capsule that surrounds the implant.

Torres et al.$^{29}$ studied the group of animals evaluated after 28 days of grafts in the larger omentum. They observed that the group presented important similarity between the splenic tissue autotransplanted and the normal tissue. The red pulp had structure of splenic tissue, with trabeculae in most of the grafts, some cicatrized areas and some macrophages. The white pulp consisted of small lymphoid follicles, with matured lymphocytes, active germinative centers, lymphoids periarterial vessels and marginal areas well differentiated. The centrofolicular artery was not well differentiated. A third of the fragments evaluated histologically, with 14 days implantation presented the persistence of small area of central necrosis, with areas of hyaline material and with phagocytes and hemosiderine pigments. 
The tissue structure of the spleen was not very defined, but there were lymphoid follicles, with absence of germinative center and marginal area. The few sinusoids found in the red pulp were dilated.

Marques et al. ${ }^{22}$ employing the microscopic analysis with hematoxilin-eosin stain of the fragments after 16 weeks of autotransplantation showed similar morphologic aspect in all of the rats, white and red pulps with moderate architectural disarrangement. Although a reduction of the white pulp was observed, lymphoid follicles were present. The decrease of the marginal area was also observed and the germinative centers were not found.

Marques et al. ${ }^{24}$ observed that the splenic tissue showed the red and white pulps, with moderate architectural disarrangement and lymphoid follicles. The blood vessels showed preserved walls, without vasculite signs or thrombosis. They were found macrophages containing clots of bacteria, as well as macrophages containing hemosiderin. The authors concluded the morphologic architecture was of a normal spleen, however of smaller dimension with conserved bacteria phagocitosis.

Torres et ll. $^{21}$ in their studies with subtotal splenectomy and replacement of $1 / 3$ of the splenic remainder inside the peritoneum cavity, observed that the tissue surface was covered for mesothelial cells and with fine capsule of fibroelastic tissue. The white pulp consisted of small lymphoid follicles, an active germinative center, periarterial lymphoid tissues and area marginal well differentiated. In the splenic capsule, small fibroblastic proliferation was observed and the red pulp also came very defined. They concluded that the growth of the grafts occurs in rats after 45 days, observing in the regeneration area great similarity to the normal splenic tissue. The group that suffered evaluation after 15 days of surgery presented initial inflammatory reaction, histologically being observed rarefaction of the splenic tissue, with macrophage prevalence and great amount of hemosiderine pigments. The structural tissue became irregular and the red pulp presented hiperplasia, without fibroblastic proliferation in the capsule and without necrosis areas. The histological study of the grafts recovered 30 days after the surgical procedure, showed thickness capsule with focuses of fibroblastic proliferation and little amount of macrophages. The white pulp was more developed, with increase of the lymphoid tissue. The red pulp showed less congestion without pattern of normal development.

Fatouros et al. ${ }^{3}$ studied the relationship between the spleen and the lipid metabolism. Concluded that the spleen has a role in lipid metabolism in rats and may therefore influence atherosclerosis. Simões et al. ${ }^{30}$ studied the lipidic profile in rats submitted to splenectomy isolated or combined with splenic autotransplant. Their findings showed that isolated splenectomy alters lipids metabolism in rats fed with standard chow and, splenic autotransplantation is effective in restoring its control.

Actually, it is proved that for the spleen to carry out their functions, it is indispensable that the sanguine drainage goes to the liver. The splenic tissue autotransplanted in subcutaneous, peritoneum and other places whose drainage is done for the systemic circulation was not viable. Thus, already a consensus exists among the authors that the greater omentum would be the place of ideal implantation, following by the mesenterium and mesocolon. This is due not only for its extension and vascularization, but, mainly, for its venous drainage to belong to the portal system, mimetizing the normal conditions of the spleen $^{22,25}$.

The more controversial methodological subject with the spleen autotransplants is the amount of the fragment of the spleen implanted that, in spite of equivalent function, is not enough to combat infections induced experimentally in the animal organisms. Consequently, to the spleen to maintain its functionality state, are necessary at least 25 to $30 \%$ of its normal tissue mass. The spleen when transplanted in fragments is better for the maintenance of the filter function because its microscopically architecture is preserved ${ }^{8,10,11}$.

The results of the present research are in according to the literature $11,19,22,24,29$. The results showed that the best place for the autotransplantation is the greater omentum and the histological analysis of the fragments recovered confirmed significant similarity with the normal splenic tissue, as for qualitative and quantitative aspects. Besides, still performing autotransplants with approximately $15 \mathrm{~mm}$ and, after six months of observation, occurring more than $30 \%$ of reduction in the weight of the grafts, the splenic tissue it seems that was functioning, because it was verified significant number of active macrophages, macrophages phagocyting hemosiderine and plasmocytes. However, we did not know how to explain the reason of the occurrence of smaller number of endothelial cells in the omentum group.

Certainly that, future researches are still necessary on this subject, to study the relationship between the spleen autotransplanted and the systemic repercussion. Until now, the review of experimental and clinical works demonstrates that the spleen tissue autotransplantation is totally viable, preserving its important function of defense of the organisms.

\section{Conclusions}

The splenic autotransplantation is feasible, being the better place the greater omentum. This research demonstrated through qualitative and quantitative histological analysis that splenic tissue autotransplanted in the omentum of Wistar rats preserves its function of defense of the organisms.

\section{References}

1. Chadburn A. The spleen: anatomy and anatomical function. Semin Hematol.

2000;37(Suppl 1):13-21.

2. Cesta MF. Normal structure, function, and histology of the spleen. Toxicol Pathol. 2006;34(5):455-5.

3. Fatouros M, Bourantas K, Bairaktari E, Elisaf M, Tsolas O, Cassioumis D. Role of the spleen in lipid metabolism. Br J Surg. 1995;82(12):1675-7.

4. Ellison EC, Fabri PJ. Complications of splenectomy: etiology, prevention and management. Surg Clin N Am. 1983;63(6):1313-30.

5. Kovacs KF, Caride VJ, Toulankian RJ. Regeneration of splenic autotransplants in sulckling and adults rats. Arch Surg. 1981; 116(3): 355-6. 
6. Rezende AM. Enxerto autólogo de baço estudo comparativo e experimental no abdome [Tese-Mestrado]. Belo Horizonte: Universidade Federal de Minas Gerais; 1989.

7. Knezevic S, Stefanovic D, Petrovic M, Matic S, Artiko V, Milovanovic A, Popovic M. Autotransplantation of the spleen. Acta Chir Iugosl. 2002; 49(3): 101-6.

8. Souza JCL, Athiê E, Marigo C, Rahal F, Fagundes DJ. Estudo da regeneração esplênica autóloga e heterotópica em ratos. Acta Cir Bras. 2005; 20(3): 253-7.

9. Tavassoli M, Ratzan RJ, Crosby WH. Studies on regeneration of heterotopic splenic autotransplants. Blood. 1973; 41(5): 701-9.

10. Velcek FT, Jongco B, Shaftan GW, Klotz DH, Rao SP, Schiffman G, Kotmeier PK. Posttraumatic splenic replantation in children. J Pediatr Surg. 1982;17(6):879-83.

11. Paredes JP, Caínos M, Pérez E, Otero R, Rodriguez S, Potel J. Valoración del autotransplante esplênico em epiplón mayor. Rev Esp Ap. Digest. 1994; 81(1): 29-33.

12. Sampaio P. Autotransplante de tecido esplênico na cavidade peritoneal. Rev Bras Cir. 1950; 20: 59-62.

13. Galvão L, Azevedo N. Enxerto autólogo de baço. Rev Bras Cir. 1980; 7(3): 143-6.

14. Kusminsky RE, Chang HH, Hossino N, Lekan SM, Boland JP. Am omental implantation technique for salvage of the spleen. Surg Gynecol Obstet.1982;155: 406-8.

15. Willians JS, Patel JM, Hinshae JR. Omental pouch technique for hemitransplantation of the spleen. Surg Gynecol Obstet. 1982; 155(5): 730-1.

16. Petroianu A, Petroianu LP. Splenic autotransplantation for treatment of portal hypertension. Can J Surg. 2005; 48(5): 3826.

17. Lau JTK, Ong GB. Experimental splenosis: a comparative study in rats. Aust N Z J Surg. 1982; 52(2): 210-5.

18. Chatterge SN, Eckles D, Gershwin ME. Preferential B. cell reconstitution following splenic autotransplantation in mice. Transplant Proc. 1979; 11(2): 1458-9.

19. Sotelo PR, Sosa VMR, Jimenez DC, Rozhkova GG. Autotrasplante libre de tecido esplénico. Rev Cub Cir. 1983; 22: 197-3.

20. Rezende AM, Silva AL, Maciel RARS. Enxerto autólogo de baço estudo comparativo e experimental no abdome. Arq
Gastroenterol. 1990; 27(4): 174-1.

21. Torres OJM, Macedo EL, Picciani ERG, Nunes PMS, Costa JVG, Carvalho AB, Lobato Jr PS. Histological study of splenic regeneration in rats underwent to subtotal splenectomy. Acta Cir Bras. 2000; 15(2):107-14.

22. Marques RG, Petroianu JM, Coelho JMCO, Portela MC. Regeneration of splenic autotransplants. Ann Hematol. 2002; 81: 622-6.

23. Miko I, Brath E, Nemeth N, Toth FE, Sipka S, Kovacs S, Sipka S Jr, Fachet J, Furka A, Furka I, Zhong R. Hematological, hemorheological, immunological and morphological studies of spleen autotrasnplantation in mice: preliminary results. Microsurgery. 2003; 23(5): 483-8.

24. Marques RG, Petroianu A, Coelho JMCO, Portela MC. Morfologia e função fagocitária de implante esplênico autógeno regenerado em ratos. Acta Cir Bras. 2004; 19(6): 642-8.

25. Paulo DNS, Paulo ICAL, Kalil M, Vargas PM, Silva AL, Baptista JFA, Guerra AJ. Subtotal splenectomy preserving the lower pole in rats: technical, morphological and functional aspects. Acta Cir Bras. 2006; 21(5): 321-7.

26. Karagulle E, Hoskoskun Z, Kutlu AK, Kaya M, Baydar S. The efectiveness of splenic autotransplantation: an experimental study. Ulus Travma Acil Cerrahi Derg. 2007;13(1):13-9.

27. Resende V, Petroianu A. Funções do remanescente esplênico após esplenectomia subtotal ou auto-implantes esplênicos para tratamento de lesões complexas do baço humano. An Fac Med Fed Pernanb. 2000; 45(2): 100-5.

28. Rodrigues Jr AJ, Rodrigues CJ, Yamamuro E, Komo E, Birolini D, Oliveira MR. Desenvolvimento de autotransplantes intraperitoneais de baço com e sem remanescente esplênico tópico (estudo experimental em ratos). Rev Hosp Clin Fac Med São Paulo. 1987; 42(5): 209-2.

29. Torres OJM, Dietz UA, Lima EJB, Loddo G, Salazar RM, Malafaia $\mathrm{O}$. Histological evalution of the regeneration of splenic autotransplants: experimental study in rats. Acta Cir Bras. 1994; 9(2): 81-7.

30. Simões FC, Marques RG, Diestel CF, Caetano CE, Dinis AP, Horst NL, Nogueira Neto JF, Portela MC. Lipidic profile among rats submitted to total splenectomy isolated or combined with splenic autotransplant. Acta Cir Bras. 2007;22(Suppl 1):461 .

\section{Correspondence:}

Nelson Adami Andreollo

Rua Francisco Humberto Zuppi, 1234

13083-350 São Paulo - SP Brazil

Phone: (55 19)3521-9447 / 3521-9450

nandreollo@hotmail.com
Conflitc of interest: none Financial source: none

Received: November 23, 2007

Review: January 15, 2008

Accepted: February 12, 2008

\section{How to cite this article}

Malagó R, Reis NS, Araújo MR, Andreollo NA. Late histological aspects of spleen autologous transplantation in rats. Acta Cir Bras. [serial on the Internet] 2008 May-June;23(3). Available from URL: http://www.scielo.br/acb

\footnotetext{
*Color figures available from www.scielo.br/acb
} 